No 4069

Studia nad Autorytaryzmem i Totalitaryzmem 43, nr 2

Wrocław 2021

https://doi.org/10.19195/2300-7249.43.2.20

\author{
PAWEŁ WIĄZEK \\ ORCID: 0000-0002-9153-4539 \\ Uniwersytet Wrocławski \\ pawel.wiazek@uwr.edu.pl
}

\title{
Między utopią a antyutopią. Krytycznie o doktrynie Jana Jakuba Rousseau w świetle kontrowersji wokół jego poglądów na istotę woli powszechnej
}

\author{
Słowa kluczowe: filozofia prawa, doktryna polityczna, oświecenie, wola powszechna, umowa \\ społeczna. \\ BETWEEN UTOPIA AND ANTI-UTOPIA: CRITIQUE OF JEAN-JACQUES \\ ROUSSEAU'S DOCTRINE IN THE LIGHT OF THE CONTROVERSY SURROUNDING \\ HIS VIEWS ON THE ESSENCE OF GENERAL WILL
}

\begin{abstract}
The article is devoted to the controversy related to the interpretation of key concepts in the doctrine of one from among the most important thinkers of the eighteenth-century Europe - JeanJacques Rousseau. The considerations are carried out on many levels, focusing on the key concept of volonté générale in the treatise $\mathrm{Du}$ Contrat social ou principes de droit politique. The applied method, exegesis of the source text, corresponds with the polemic that has been conducted for decades, creating a rich literature on the subject. Selecting the positions of many distinguished researchers, the author attempts to confront Rousseau's views with the flagship triad of basic values of the Great French Revolution: freedom, equality, and fraternity. This allowed the formulation of numerous comments, assessments, and opinions, at least some of which could be considered polemical or directly controversial
\end{abstract}

Keywords: philosophy of law, political doctrine, enlightenment, general will, social contract. 


\section{O relacjach między utopią pozytywną a negatywną}

W języku potocznym słowo „utopia” oznacza zazwyczaj mrzonkę, chimerę, wytwór nieliczącej się z faktami fantazji, projekt, którego urzeczywistnienie nie jest możliwe ${ }^{1}$. W świecie nauki definiowana jest najczęściej jako projekt lub przedstawienie doskonałego ustroju politycznego, opierającego się na sprawiedliwości, solidarności i równości. W bogatej literaturze przedmiotu reprezentowany jest pogląd, w myśl którego w szerokim rozumieniu zakres semantyczny utopii winien obejmować wszelkie systemy poglądów ugruntowane na sprzeciwie wobec aktualnie istniejących stosunków i przeciwstawianiu im propozycji stosunków innych, bardziej odpowiadających istotnym potrzebom ludzkim ${ }^{2}$. Pojęcie utopii spopularyzował w eseju z XVI wieku Thomas More, kreślący alegoryczny obraz abstrakcyjnego społeczeństwa i państwa idealnego ${ }^{3}$.

Proweniencja terminu nie budzi poważniejszych kontrowersji. Można oczywiście przyjąć perspektywę spojrzenia apologety tej idei, dostrzegającego w niej

najpowszechniejszy pierwiastek w świecie ducha; składnik wszystkich wierzeń religijnych, teorii moralnych i prawnych, systemów wychowawczych, utworów poetyckich, słowem, wszelkiej wiedzy i twórczości, dającej wzory życia ludzkiego, [...] bowiem gdzie tylko istnieją - a istnieją zawsze i wszędzie - nędza, krzywda i boleść, tam musi zjawić się rozważanie usunięcia przyczyn złego. W olbrzymiej skali, która rozciąga się przez całą historię kultury, od rojeń dzikiego koczownika, do rozmyślań nowoczesnego filozofa, mieści się niezliczona ilość odmian utopii ${ }^{4}$.

Zachowując jednak odrobinę dystansu wobec podobnej ekspresji przepojonej bezmiarem empatii ${ }^{5}$, wypada przychylić się do powszechnej opinii, uznającej

1 J. Szacki, Spotkania z utopia, Warszawa 2000, s. 16.

2 M. Głażewski, Terra Utopia. Glosy i konteksty pedagogiczne utopii, http://www.repozytorium.uni.wroc.pl/Content/89288/PDF/3_Glazewski_Michal_Terra_utopia.pdf, s. 28-29; za: J. Szacki, op. cit., s. 24-25.

3 T. More, Libellus vere aureus nec minus salutaris quam festivus de optimo reipublicae statu, deque nova insula Utopia, Louvain 1516 [Reprint of the Original from 1516 (Latin Edition), EOD Network 2013]. Stosunkowo skromne objętościowo, dwutomowe dzieło po raz pierwszy opublikowane zostało staraniem wydawcy z Louvain, Thierry'ego Martinsa; por. T. Vanderstappen, Thomas More and his Utopia: The Leuven Connection, „The Brussels Times”, 7.11.2016, https://www.brusselstimes.com/opinion/39946/thomas-more-and-his-utopia-the-leuven-connection/ (dostęp: 22.01.2021). Po ukazaniu się Utopii w 1516 roku ruszyła lawina jej kolejnych łacińskich wydań. Wychodziły one jedno po drugim spod pras drukarskich w Paryżu, Bazylei, Florencji, Wenecji, Wiedniu, Kolonii, Wittenberdze, Frankfurcie, Hanowerze, Mediolanie, Amsterdamie, Oksfordzie, Londynie, Glasgow i Berlinie. Pierwszym angielskim tłumaczeniem Utopii było wydanie w przekładzie Ralpha Robinsona z roku 1551. Pierwszy polski przekład dokonany przez Kazimierza Abgarowicza pochodzi z roku 1947; zob. P. Rutkowski, Polityczne korzenie „Utopii” Tomasza Morusa, „Odrodzenie i Reformacja w Polsce" 45, 2001.

4 A. Świętochowski, Utopie w rozwoju historycznym, Warszawa 1910, s. 7.

5 Zob. na przykład F. Graus, utrzymujący, że ,zanim utopijne koncepcje Platona mogły się rozpowszechnić w Europie, przez całe wieki pozostawały »w uśpieniu« i na zbudzenie musiały 
antyczny, grecki rodowód utopii, utożsamiany z dziełami Platona ${ }^{6} \mathrm{i}$ innych myślicieli starożytnej Hellady ${ }^{7}$. Pewne wątpliwości pojawiają się czasami na tle poszukiwań etymologicznych, które wskazują także na grecki źródłosłów ${ }^{8}$.

O ile utopia przedstawia wizję idealnej, to antyutopia (zwana czasami również utopią negatywną) stanowić ma jej przeciwieństwo, jako projekcja świata przyszłości, którego organizacja polega na ograniczaniu wolności jednostki poprzez całkowite podporządkowanie jej systemowi władzy, gdzie doskonały porządek społeczny opiera się najczęściej na całkowitym kontrolowaniu ludzi, czyniącym z nich bezwolne przedmioty. Tym samym obnaża ona prawdę o iluzoryczności utopijnego ideału w wyobrażalnej rzeczywistości. W istocie ukazuje obraz społeczeństwa podporządkowanego dyktaturze, sterroryzowanego przez totalitaryzm. W jego bowiem barwach przedstawia ostatecznie pozorność dobrobytu, równości i wolności, których obietnicą tak chętnie kuszą utopiści.

Utopia i antyutopia są pojęciami, które w świadomości powszechnej koegzystują najczęściej w logice kontradyktoryjności. Ich przeciwstawny charakter często przedstawiany bywa obrazowo w ujęciu idealny świat versus piekło dyktatury. Innymi słowy, o ile utopie pozytywne stanowią sumaryczne ujęcie cech społeczeństwa doskonałego, o tyle utopie negatywne - analogiczne ujęcie społeczeństwa złego (w projekcji hipotetycznej). Niezaprzeczalny urok prostoty podobnego zestawienia bywa jednak często tyleż uwodzicielski, co zwodniczy. Warto bowiem pamiętać, że prostota bywa nierzadko iluzją niebezpiecznie balansującą na granicy uproszczenia, bliskiego już prostactwu myśli. Upatrywanie w negatywnych utopiach jedynie odwrócenia charakterystycznej dla utopii pozytywnych opozycji ideału i rzeczywistości niepokojąco zdaje się potwierdzać podobne obawy. Można przecież relację między utopią i antyutopią przedstawić zupełnie inaczej — choćby jako polemikę z utopijnymi wyobrażeniami o świecie doskonałym. Nie jako stojące w totalnej opozycji, lecz przeciwnie, jako wzajemne uzupełniające się

poczekać do końca średniowiecza. Powodem tej znaczącej przerwy w utopijnej tradycji był średniowieczny brak zainteresowania utopią. Ludzie tego okresu wierzyli, że w zmiennym świecie żadna rzecz stworzona przez człowieka nie jest w stanie osiągnąć doskonałości, która z definicji możliwa jest jedynie poza ziemskim czasem i przestrzenią. W swym pragnieniu ideału ludzie liczyli raczej na lepszy świat oczekujący ich po śmierci”, idem, Social Utopias in the Middle Ages, „Past and Present" 38, 1967, s. 5.

6 „Pierwszą wykończoną utopię dał Platon (427-347) w dwóch dziełach: Państwie (Politeia) i Prawach (Nomoi)", A. Świętochowski, op. cit., s. 10.

7 Na przykład Arystotelesa (pisma o państwie w Polityce) czy Ksenofonta (Cyropedia); por. M. Głażewski, op. cit., s. 29.

8 Pochodzenie terminu nie jest jednoznaczne. Słowo ,topia” (od greckiego topos/ $\theta \dot{\varepsilon} \sigma \eta$ ) oznaczało miejsce. Poprzedzająca to słowo litera „u” mogła pochodzić od greckiego eu/\&v lub ou/ov́.

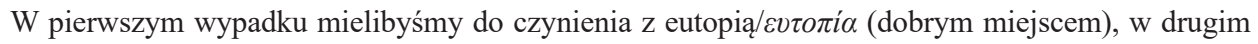
— z outopią (miejscem, którego nie ma). Za wysoce prawdopodobne uznaje się, że „,niepoprawny kalamburzysta" More celowo wykorzystał taką dwuznaczność, zaś jego Utopia była jednym i drugim; por. J. Szacki, op. cit., s. 11-12. Por. także R. Brandwajn, Utopia walczaca, Warszawa 1962, s. 15-16; The Oxford companion to English literature, red. M. Drabble, Oxford 1994, s. 1019. 
elementy, między którymi granica jest nie wyrazista, lecz płynna. Czyż tak oczywistym jest absurdalność spojrzenia na antyutopię jako odpowiedź na zagrożenia płynące z bezkrytycyzmu wielu autorów utopii, przekonanych niejednokrotnie o niekwestionowanej doskonałości ich subiektywnej wizji alternatywnej rzeczywistości? Czyż dzieje ludzkich cywilizacji nie dowiodły tego, jak bliska jest granica między szlachetnymi intencjami wizjonera powszechnej szczęśliwości, kreatora nowego, wspaniałego świata, któremu przyświecają piękne i wzniosłe idee a koszmarem totalitarnej rzeczywistości powstałej w wyniku urzeczywistnienia jego wizji? Czy, nomen omen, utopijnym jest wniosek uznający, że utopia może przekształcać się w antyutopię? Wystarczy przecież ogląd rzeczy przez prymat innego systemu wartości, przez konstatację: „,marzenia jednego człowieka są koszmarem innego" ", by konstrukcja prostej opozycji utopii do antyutopii z hukiem legła w gruzach.

\section{Rousseau jako ikona europejskiego oświecenia}

O Janie Jakubie Rousseau panuje powszechne przekonanie jako o osobowości pełnej sprzeczności, filozofie chętnie przywoływanym i często opacznie rozumianym ${ }^{10}$. I trudno jest ze zdaniem tym się nie zgodzić. Imponujące zdaje się zwłaszcza szerokie spektrum jego zainteresowań ${ }^{11}$, korespondujące ze śmiałością, oryginalnością i kontrowersyjnością formułowanych tez. Jego poglądy do dziś stanowią przedmiot zainteresowań zarówno luminarzy, jak i mniej znanych adeptów wielu dyscyplin naukowych ${ }^{12}$.

W spojrzeniu na postać i twórczość obywatela Genewy nie sposób niemal oprzeć się wrażeniu wszechobecnej paradoksalności, a jednocześnie nietuzinkowości. Dotyczą one zarówno jego biografii, głoszonych poglądów, jak i samej jego obecności wśród największych myślicieli osiemnastego stulecia. Uznawany powszechnie za jednego $\mathrm{z}$ najwybitniejszych reprezentantów filozofii oświecenia, wymieniany w jednym rzędzie obok takich myślicieli, jak Voltaire, D. Diderot, J. Locke, J. d'Alembert, D. Hume czy Ch.L. de Montesquieu, w swych

9 M. Mead, Towards More Vivit Utopias, [w:] Utopia, red. G. Kateb, New York 2017, s. 44.

10 A. Porada, Jan Jakub Rousseau - filozof w stanie natury, https://www.polityka.pl/tygodnikpolityka/historia/1528293,1,jan-jakub-rousseau---filozof-w-stanie-natury.read (dostęp: 19.01.2021).

11 Na przykład w dziedzinie muzyki zasłynął między innymi jako autor opery Le Devin $d u$ Village i zwolennik poglądu akcentującego znaczenie melodii i przekazywania emocji jako centralnych elementów funkcji muzyki. W historii literatury uznawany jest za twórcę sentymentalizmu i powieści epistolograficznej, których wyrazem miała być jego powieść Nowa Heloiza. W pedagogice wciąż niesłabnącym zainteresowaniem cieszą się jego poglądy, którym dał wyraz w dziele Emil, czyli o wychowaniu, uznawanym za jeden z najważniejszych nowożytnych traktatów pedagogicznych wszechczasów.

12 Szerzej na ten temat zob. na przykład M. Ludwisiak, Postać Jana Jakuba Rousseau i jego wpływ na współczesnych, „Acta Universitatis Lodziensis. Folia Historica”, 2007, nr 81, s. 87-108. 
poglądach kwestionuje fundamentalne wartości epoki: racjonalizm, uniwersalizm, empiryzm czy umiłowanie nauki i sztuki. Prowadząc permanentną niemal polemikę $\mathrm{z}$ jednostronnie racjonalnym kształtowaniem życia, niezależnie od tego, że w swojej krytyce oświecenia miał na przestrzeni XVIII wieku niebanalnych poprzedników (vide J.O. de La Mettrie ${ }^{13}$ ), Rousseau godził przecież w podstawy oświecenia; w okresie uwielbienia dla cywilizacji i rozumu bronił praw prostej natury i uczucia.

Wszystko to nie przeszkodziło mu jednocześnie zaskarbić sobie miana „twórcy nauk humanistycznych” czy „prekursora socjologii” ${ }^{14}$, niezależnie od reprezentowanego w nauce poglądu o sprzecznościach w doktrynie Rousseau i niekonsekwencji metodologicznej ${ }^{15}$ całej twórczości autora Contrat Social ${ }^{16}$. Niezrozumiała sprzeczność? Niekoniecznie.

Analogicznie rzecz ma się z pozycją Rousseau w epoce „wieku filozofów”. Za wybitnie krytyczny wobec myślicieli swoich czasów uznać należy jego pogląd sytuujący ich pośród post-hoc racjonalizatorów własnego interesu, apologetów różnych form tyranii, odgrywających niepośrednią rolę $\mathrm{w}$ wyobcowaniu jednostki od naturalnego ludzkiego odruchu współczucia ${ }^{17}$. A jednak pomimo, lub paradoksalnie dzięki temu, że jego własna opinia o filozofii i filozofach była tak wybitnie krytyczna, a poglądy tak dalece odbiegały od głównego nurtu czasów oświecenia, uchodzi on jednocześnie za jego ikonę, czego potwierdzeniem jest teza, że ostatnie cztery dekady XVIII stulecia — „wieku systemów” — upływają w Europie pod znakiem kultu postaci filozofa-pisarza Jana Jakuba Rousseau ${ }^{18}$.

$\mathrm{Na}$ temat osoby i twórczości obywatela Genewy napisano już tysiące słów i wygłoszono setki opinii. Czy jednak rozstrzyga to ostatecznie o wyeksploatowaniu przestrzeni potencjalnych eksploracji związanych jego poglądami? Wprost przeciwnie. Nie tyle bowiem sama tylko tematyka, ile w zdecydowanie większym stopniu aspekt i sposób jej przedstawienia decydują o wartości pracy badawczej, analogicznie do artystycznej. W kontekście poglądów Rousseau zasadność takiego twierdzenia wzmacniają ich waga, uniwersalizm i aktualność. Wciąż powszechna jest bowiem teza o wyjątkowym ich znaczeniu, zarówno ze względu na

13 Ibidem, s. 87.

14 C. Lévi-Strauss, Jan Jakub Rousseau, Twórca nauk humanistycznych, przeł. L. Kolankiewicz, „Twórczość” 1984, nr 6; por. P. Urbański, Jean Jacques Rousseau: oświecenie a soba-pisanie, „Filozofia i Nauka. Studia filozoficzne i interdyscyplinarne” 5, 2017, s. 171.

15 Szerzej na ten temat zob. zwłaszcza A. Melzer, The Natural Goodness of Man: On the System of Rousseau's Thought, Chicago 1990, passim.

16 Por. B. Baczko, Rousseau, Samotność i wspólnota, Warszawa 1964.

17 Ch. Bertram, Jean Jacques Rousseau, [hasło w:] The Stanford Encyclopedia of Philosophy (wydanie zimowe 2020), red. E.N. Zalta, https://plato.stanford.edu/archives/win2020/entries/rousseau (dostęp: 20.01.2021).

18 L. Ludwisiak, op. cit., s. 87. 
swój wkład w filozofię polityczną i psychologię moralną, jak i wpływ na późniejszych myślicieli ${ }^{19}$.

Warto w tym miejscu przytoczyć uwagę, że na pytanie „czemu (w pierwszym rzędzie) Jean-Jacques Rousseau zawdzięcza swą sławę"?, Encyklopedia Britanni$c a^{20}$ spośród wielu możliwych odpowiedzi, udziela takiej: uznaniu „umowy społecznej za porozumienie między jednostką a zbiorową "wolą powszechną«, której celem jest dobro wspólne, odzwierciedlone w prawach państwa idealnego"21. To tylko jedna z wielu przyczyn i jeden z wielu argumentów przesądzających o decyzji co do clou naszych eksploracji.

Nie sposób nie zgodzić się z dość powszechną tezą, uznającą poglądy Rousseau o istocie woli powszechnej za wątpliwie konsekwentne, sprecyzowane, logiczne i spójne, a tym samym za nacechowane niejasnościami rodzącymi naturalne wątpliwości i w konsekwencji — różnorodność interpretacyjną. Historia polemiki toczonej w obrębie tej problematyki przez dziesiątki lat imponowała i wciąż imponuje wielowątkowością i bogactwem sprzecznych często opinii. Niewątpliwie to te właśnie niejasności i nieścisłości spowodowały zainteresowanie komentatorów niemal już nazajutrz po pierwszej ich publikacji. Przesądziły jednocześnie o wielopłaszczyznowości i wieloaspektowości toczonego dyskursu.

Jedną z wielu jego konwencji jest na przykład dychotomiczne ujęcie sporu $\mathrm{w}$ formie alternatywy między utożsamianiem poglądów autora Umowy społecznej z koncepcją demokratyczną, w której powszechna wola jest po prostu tym, co obywatele państwa postanowili wspólnie w swoim suwerennym zgromadzeniu, a alternatywną interpretacją, że wola ta jest transcendentnym wcieleniem wspólnego interesu obywateli, wyabstrahowanego od tego, czego każdy z nich rzeczywiście pragnie ${ }^{22}$. Inną formułą dysputy może być układ trójdzielnej sekwencji, współtworzonej w oparciu o relację woli jednostkowej z wolą zbiorową. W takim ujęciu pierwsza propozycja oparta byłaby na uznaniu, że wszystkie jednostki mają prywatną wolę odpowiadającą ich własnym egoistycznym interesom jako jednostkom fizycznym. Drugą byłaby perspektywa przyjmująca, że każda jednostka, o ile utożsamia się ze zbiorowością jako całością i przyjmuje tożsamość obywatela, chce, aby ogólna wola tego kolektywu była swoją własną, odkładając na bok samolubne interesy na rzecz zbioru praw, które pozwalają wszystkim koegzystować na warunkach równej wolności. Wreszcie trzecią — propozycja

19 Ch. Bertram, op. cit.

20 Sięgająca swymi początkami czasów oświecenia, szanowana powszechnie anglojęzyczna encyklopedia powszechna, wydana po raz pierwszy w latach 1768-1771 w Edynburgu przez Colina Macfarquhara i Williama Smellie'a, a od 1901 wydawana w Stanach Zjednoczonych. Od 2012 roku wychodzi tylko w wersji online.

21, ,S] ocial contract as a compact between the individual and a collective »general will« aimed at the common good and reflected in the laws of an ideal state and for maintaining that existing society rests on a false social contract that perpetuates", B. Duignon, Jean-Jacques Rousseau, [hasło w:] Britannica, https://www.britannica.com/biography/Jean-Jacques-Rousseau (dostęp: 20.01.2021).

22 Ch. Bertram, op. cit. 
uznająca zasadność założenia, że osoba może identyfikować się z korporacyjną wolą podgrupy, populacji, jako całości ${ }^{23}$.

Akceptując pomysł trójdzielnej ekspozycji polemicznej można jednak pokusić się o zaproponowanie innej jeszcze konwencji przedstawiającej kontrowersje wokół istoty pojęcia woli powszechnej u Jana Jakuba Rousseau. Oryginalna i nowatorska wydaje się projekcja jego poglądów w ujęciu ich relacji do sztandarowych haseł Wielkiej Rewolucji Francuskiej, która tak chętnie sięgała do filozofii politycznej obywatela Genewy: wolności, równości i braterstwa. Ryzykowne? Zapewne, zwłaszcza, jeśli zachowujemy świadomość tego, że debaty dotyczące zgodności i kolejności tych trzech terminów rozpoczęły się w tym samym czasie co rewolucja. Czasami jednak warto takie ryzyko podjąć nawet wtedy, gdy wszystkie znaki na niebie i ziemi wskazują, że powodzenie podobnego projektu graniczy z niemożliwością. Trudno bowiem wyobrazić sobie rozwój nauki, ograniczając badania wyłącznie do utartych, eksploatowanych już kanonów. Nie aspiruję przy tym bynajmniej do tego, by w podobnym projekcie przedstawić obraz kompletny i skończony, choćby tylko w zakresie granic wytyczonych przyjętą konwencją. Nie byłoby to już bowiem balansowaniem na granicy, lecz jałowym buszowaniem w krainie niemożliwego, nie będącym niczym więcej niż autodyskredytacją z kategorii nowego wymiaru ignorancji.

Wola powszechna jest kluczowym zagadnieniem w koncepcji umowy społecznej Rousseau. Czymże jednak ona jest? Odpowiedź filozofa na to, podstawowe przecież, pytanie z pewnością nie jest precyzyjna. Pisząc o woli powszechnej ma przeważnie na myśli jej ujęcie racjonalistyczne, traktuje ją jako ,wolę rozumną", wyrażającą dobro wspólne danej społeczności. Czasami jednak stosuje do niej ujęcie empiryczne, traktując ją jako faktyczną wolę wyrażaną przez daną wspólnotę w głosowaniu, wolę, która nie zawsze musi być tożsama $\mathrm{z}$ uświadomionym dobrem wspólnoty ${ }^{24}$.

Choć idea woli powszechnej pojawia się w wielu traktatach Rousseau, to jednak zasadnym jest uznanie, że kluczowe znaczenie mają jego poglądy przedstawione w będącym niemal przedmiotem kultu traktacie Du contrat social ou Principes du droit politique. Współczesne rozważania epistemiczne koncentrują się głównie wokół uwag autora zamieszczonych w trzecim rozdziale księgi drugiej tego dzieła, zatytułowanym: Czy wola powszechna może błądzić (Si la volonté générale peut errer) oraz w pierwszym rozdziale księgi czwartej, której nadano tytuł Wola powszechna jest niezniszczalna (Que la volonté générale est indestructible $)^{25}$.

23 Ibidem.

24 J. Bacławski, Wola powszechna i jej stabilność wedtug koncepcji J.J. Rousseau, „Przegląd Filozoficzny - Nowa Seria” 21, 2012, nr 4, s. 183.

25 Fundamentem źródłowym jest polskojęzyczna wersja traktatu w przekładzie A. Peretiatkowicza (J.J. Rousseau, Umowa społeczna, przeł. A. Peretiatkowicz, Kęty 2007; dalej: Umowa spoteczna), którą dla potrzeb weryfikacji konfrontowano z francuskojęzyczną jego wersją, którą jest 


\section{Liberté et la volonté générale}

„Wola powszechna jest zawsze słuszna i zmierza zawsze ku korzyści ogólnej26", śmiało twierdzi Rousseau. Tyle że poza kontekstem i bez uzasadnienia twierdzenie to jest zwyczajnie gołosłowne. To jednak dopiero początek złotych myśli autora Contrat Social na temat woli powszechnej; wypada więc dać szansę panegiryście, pokładając nadzieję w proroczym charakterze słów Ewangelii ${ }^{27}$. Na szczery podziw zasługuje moim zdaniem ten, kogo przekonuje, że

różnica między wolą wszystkich a wolą powszechną [polega na tym, że - P.W.] ta ostatnia uwzględnia interes wspólny, tamta — interes prywatny i jest tylko sumą woli prywatnych; ale odejmijmy od tych samych woli plusy i minusy, które się nawzajem znoszą, a pozostanie jako wynik tych różnic — wola powszechna.

Szczególne uznanie należne jest w tym miejscu A. Peretiatkowiczowi, który nie waha się przedstawić własnej interpretacji tych słów ${ }^{28}$.

Gdybyż tylko problem ,woli powszechnej” można było sprowadzić do ułomności czytelnika, jego ignorancji i godnego politowania braku umiejętności zrozumienia słów mistrza, nie byłoby się czym zajmować. Jednak gdy beztroskę niezrozumienia zaczyna zastępować niepokój, żarty się kończą. A mogą go wywołać słowa definiujące wolność jako, ,zdolność do pełnego stosowania i gotowość do bycia kierowanym przez wolę powszechną" 29 . W tym kontekście niewiele zmienia kontrowersyjne twierdzenie Rawlsa utrzymującego, że według Rousseau wszyscy ludzie mają równą zdolność do bycia wolnymi i są równie zainteresowani wolnością ${ }^{30}$. Podobnie uwaga M. Webera, dostrzegającego we władzy szansę na przeprowadzenia swej woli we wspólnotowym działaniu przez jednostki lub wielu

w tym wypadku amsterdamskie wydanie z 1762 roku (1758-août 1761, Bibliothéque publique et universitaire de Geneve (première version); ,Le manuscrit contenant la version définitive du Contrat social qui a été imprimée a disparu." le Pléiade édition t. III, p.1866. Publication, Amsterdam, février-mars 1762, Marc Michel Rey, etc.; le Pléiade édition t. III, pp. 347-470, 1866-1874. Du Peyrou/Moultou 1780-1789 quarto édition; t. I, pp. 187-360 (1782) dostępne na stronie https:// www.rousseauonline.ch/Text/du-contrat-social-ou-principes-du-droit-politique.php (dalej: Contrat social) (dostęp: 25.01.2021).

26 Umowa społeczna, s. 28.

27 ,[S]zukajcie, a znajdziecie”; Mt 7, 7.

28 Przypis 13: „Znaczenie tego trudnego ustępu wywołuje liczne spory w literaturze naukowej. Co do mnie, sądzę, że proponowane tłumaczenia nie są trafne i że woli prywatnej nie należy tu rozumieć w formie woli faktycznie istniejącej (bo tej nie można dzielić na składniki nadające się do działań arytmetycznych), ale w znaczeniu interesu prywatnego. Rousseau chce powiedzieć, że interes każdej jednostki nakazywałby jej żyć kosztem społeczeństwa, to znaczy wziąć sobie »więcej«, a innym zostawić »mniej«. Ponieważ jednak interes każdej jednostki jest podobny, więc te »plusy« $\mathrm{i}$ »minusy« znoszą się ze stanowiska społecznego, a pozostaje tylko to, co leży w interesie wszystkich", Umowa społeczna, s. 29.

29 J. Bacławski, op. cit., s. 190.

30 J. Rawls, Wykłady z historii filozofii polityki, Warszawa 2010, s. 301; por. J. Bacławski, op. cit., s. 185. 
ludzi, także wbrew oporowi innych jego uczestników ${ }^{31}$. Rousseau stawia bowiem w tym przypadku sprawę wyjątkowo, jak na swoje zwyczaje, jasno, stwierdzając: „Jak natura daje każdemu człowiekowi władzę absolutną nad wszystkimi jego członkami, tak umowa społeczna daje ciału politycznemu władzę absolutną nad wszystkimi jego członkami; ta właśnie władza, kierowana [jest - P.W.] przez wolę powszechną" "32. Jeśli nawet przyjmiemy za stoikami, że wolność to umiejętność zrozumienia konieczności rządzących światem i świadome podporządkowanie się $\mathrm{im}^{33}$, nie oznacza to jeszcze konieczności podporządkowania się enigmatycznej woli powszechnej, podobnie jak tego, że ta eteryczna figura retoryczna rządzi światem.

Wszystko to jednak wyda się niewiele znaczącą igraszką w momencie, w którym filozof oznajmia, że ,jeśli ktokolwiek odmówi posłuszeństwa woli powszechnej, będzie do tego zmuszony przez całe ciało; co nie oznacza niczego innego jak tylko to, że będzie zmuszony do wolności" ${ }^{34}$. Z punktu widzenia klasycznego pojmowania wolności, w którym przymus stanowi jej antytezę, stanowisko to jest nie do przyjęcia, jako obrazoburcze. Entuzjaści geniuszu obywatela Genewy będą go jednak zapewne bronić z pozycji heglowskiej koncepcji dwóch wolności: pozytywnej i negatywnej (,do" i „od”) 35 , perorując o ,przymusie wyższego rzędu" ${ }^{36}$. Ten przymus miał wkrótce uzyskać wymiar bardzo konkretny, gdyż po ustanowieniu „liberalnej wolności” rewolucjoniści twierdzili, że „prawdziwa" wolność związana jest z przemocą. Saint-Just ze śmiertelną przecież powagą i całą otwartością głosił, że „Rewolucje kroczą od słabości do śmiałości i od zbrodni do cnoty [...]. Na mieczu jedynie oprzeć można wolność ludu"37.

Tego, czym są „spełnione marzenia” miłośnika „zmuszania do wolności” nie dowiodła dopiero praktyka wielkich, dwudziestowiecznych totalitaryzmów. Znacznie wcześniej uczynili to francuscy jakobini, nie przypadkiem tak chętnie powołujący się na poglądy autora Umowy społecznej. On le forcera d'être libre,

31 M. Weber, Gospodarka i społeczeństwo. Zarys socjologii rozumiejacej, Warszawa 2002, s. 679; por. M. Kunicka, Władza, przymus $i$ wolność w edukacji, „Opuscula Socjologica” 2012, nr 1, s. 35.

32 Umowa społeczna, s. 30.

33 M. Baranowska, Marzenie o szczęściu, czyli idea prawa natury w filozofii Jana Jakuba Rousseau, „Czasopismo Prawno-Historyczne” 65, 2013, z. 2, s. 66.

34 Umowa społeczna, s. 22.

35 Rozróżnienie to, którego początki łączone są z osobą Martina Luthera, swoje najpełniejsze chyba rozwinięcie znalazło w poglądach Georga Wilhelma Hegla. Pierwsza wyraża się w świadomości „siebie jako istoty myślącej, ponoszącej odpowiedzialność za wybory, których się dokonuje i potrafiącej wyjaśnić je w odniesieniu do własnych idei i zamierzeń", I. Berlin, Dwie koncepcje wolności i inne eseje, Warszawa 1991, s. 129. Natomiast ,wolność od” ,umożliwia całkowitą swobodę bycia i działania według własnej woli, bez wtrącania się, ingerencji innych osób, bez ponoszenia odpowiedzialności”, M. Czerepaniak-Walczak, Pedagogika emancypacyjna. Rozwój świadomości krytycznej człowieka, Gdańsk 2006, s. 19. Por. M. Kunicka, op. cit., s. 35.

36 Por. ibidem.

37 A.L. de Saint-Just, Wybór pism, przeł. J. Ziemilski, B. Kulikowski, Warszawa 1954, s. 100. 
to hasło wielkiego terroru i najmroczniejszego koszmaru; nie pojmuję, jak można traktować podobną ideę w kategoriach cnoty ${ }^{38}$.

Jeśli nawet urzekającymi wydadzą się słowa genewczyka, że wolność to postępowanie zgodne z własną wolą, warto pamiętać, że zdanie to jest uwarunkowane. Jest tak jedynie wówczas, gdy wola ta jest doskonale zgodna $\mathrm{z}$ wolą innych, to jest wolą powszechną, co z kolei dla ikony oświecenia jest rzeczą tak oczywistą, że niewartą wiarygodnego uzasadnienia. Jako żywo nasuwa to na myśl skojarzenie $\mathrm{z}$ wiekową niemal dykteryjką o wolności wyboru koloru samochodu ${ }^{39}$.

\section{4. Égalité et la volonté générale}

Kontestowanie powszechnego poglądu uznającego, że myśl społeczna Jana Jakuba Rousseau stanowi punkt centralny w systemie idei egalitarnych epoki francuskiego oświecenia ${ }^{40}$ byłoby z pewnością bezzasadne, przez co niezbyt poważne. W kontekście interesującej nas problematyki ma on znaczenie kluczowe. Według pozornie pięknie brzmiącej deklaracji genewskiego wizjonera podstawowymi prawami są wolność i równość. Już to twierdzenie uznać można jednak za dyskusyjne. Wiele zależy bowiem od tego, jak definiujemy obie te wartości. Należy uchylić kapelusza, gdy ikona oświecenia dowodzi swych demagogicznych zdolności, argumentując, że każdy człowiek będąc z natury wolnym i równym innym, na zasadzie wzajemności będzie traktować innych, ponieważ miłość własna determinuje każdego, by dbał o swoją pomyślność, która istnieć nie może poza społecznością równych. Chapeau bas, pomijając, że to jednak ponownie raczej deklaracja niż argumentacja.

Im bardziej wnikliwe zaczniemy przyglądać się wizji równości twórcy Contrat Social, wyłaniający się z niej obraz zacznie stawać się coraz mniej idylliczny. Prawda jest taka, że Rousseau traktował własność prywatną z jednej strony jako nienaruszalną, a z drugiej państwo w jego koncepcji miało wyrównywać naturalne nierówności między istotami ludzkimi. Od niego właśnie jakobinizm przejął gorącą wiarę w równość praw, a także żarliwe poszukiwanie dróg do „równości rzeczywistej" ${ }^{41}$.

38 Zob. J. Bartyzel, Jakobini byli roussoistami, https://teologiapolityczna.pl/prof-jacek-barty zel-jakobini-byli-roussoistami (dostęp: 25.01.2021).

39 Potencjalny nabywca pyta sprzedawcę w salonie samochodowym: „Czy mogę wybrać pojazd w dowolnym kolorze?”. „Ależ, naturalnie”, odpowiada sprzedawca; „,pod warunkiem, że będzie to kolor czarny".

${ }^{40}$ M. Blaszke, Umowa społeczna J.J. Rousseau — polityka i racjonalność, „Archiwum Historii Filozofii i Myśli Społecznej” 32, 1987, s. 41.

41 Por. J. Derek, Ideał nowego państwa Jana Jakuba Rousseau i Rewolucja Francuska, ,Studia Politicae Universitatis Silesiensis" 2009, nr 4-5, s. 24; J. Baszkiewicz, S. Meller, Rewolucja Francuska 1789-1794. Społeczeństwo obywatelskie, Warszawa 1983, s. 94. 
„Wola prywatna dąży z natury swej do prerogatyw, a wola powszechna do równości”42. Czy aby jednak na pewno dąży ,z natury swej”? Jak ma się to do postulatu zakładającego, że „by [...] mieć prawdziwy wyraz woli powszechnej, ważnym jest, by nie było w państwie społeczeństwa częściowego [...]. Skoro są już społeczeństwa częściowe, należy pomnożyć ich ilość, by zapobiec nierówności”“33? Jak „pomnożyć”? „Przymuszając do wolności”?

Jakkolwiek zgrabnie nie wdzięczyłby się genewczyk do miłośników egalitaryzmu, twierdząc, że ,wola powszechna, czyli zwierzchnia powinna stanowić zawsze obowiązującą i jedyną regułę dla wszystkich [...]"44, umiejętnie promując przy tym swoje ukochane dziecko - volonté générale, nie sposób pozbyć się wątpliwości, czy aby dla filozofa rzeczywiście równość i wolność zajmują tę samą pozycję jako „podstawowe prawa”. Przekonanie o tym, że powtarzanie największej nawet niedorzeczności odpowiednią liczbę razy uczyni cuda w świadomości odbiorcy nie jest epokowym odkryciem, zaś do mnie nie przemawia w ogóle. Za nużące i bezproduktywne uznaję więc zabiegi autora powtarzającego ponownie, że

z jakiejkolwiek strony wracamy do zasady, dochodzimy zawsze do tego samego wniosku, mianowicie, że umowa społeczna wprowadza taką równość między obywatelami, iż wszyscy zobowiązują się na tych samych warunkach i wszyscy winni o korzystać z tych samych praw ${ }^{45}$.

„Źródłem wszelakiego zła jest nierówność”46. To nie brzmi już jak samo tylko stwierdzenie czegoś, co komuś wydać się może oczywistością. To brzmi jak zapowiedź rewolucji i to niekoniecznie takiej, którą można byłoby później nazwać chwalebną.

Gdyby egalitaryzm Rousseau sprowadzał się jedynie do kwestionowania nierówności politycznej, byłby wówczas może niezbyt oryginalnym, ale z pewnością godnym odnotowania głosem w publicznym dyskursie. Gdy jednak idea równości wkracza w sferę kondycji ekonomicznej jednostek, ujawniona os tatecznie wrogość wobec własności indywidualnej staje się chwilami niemal obsesyjna, zbliżając się tym samym do przypisywanemu Prudhonowi hasła: La propriété, c'est le vol! ${ }^{47}$. Z Umowy spolecznej wyłania się upiorna twarz ochlokratycznego rewanżyzmu mas nad elitami. Jedynie ogół „obywateli” jest bowiem panem wszystkich dóbr i ma prawo wydać jakiekolwiek postanowienia kwestionujące dotychczasowe stosunki w jakiejkolwiek dziedzinie. Jedną z zasad Contrat Social jest prawo ogółu (utożsamiane przecież z wolą powszechną) do tego, by za pomocą państwa

42 Umowa społeczna, s. 26.

43 Ibidem, s. 29.

44 Ibidem, s. 53.

45 Ibidem, s. 32.

46 Zob. J. Bacławski, op. cit., s. 184.

47 P.-J. Proudhon, Qu'est-ce que la Propriété?, ou, recherches sur le principe du droit et du gouvernement. Premier mémoire, Paris 1840, s. 2, https://books.google.pl/books?id=hu_-vQAA$\mathrm{CAAJ} \&$ printsec $=$ frontcover\&redir_esc $=\mathrm{y} \& \mathrm{hl}=\mathrm{pl} \# \mathrm{v}=$ onepage $\& \mathrm{q} \& \mathrm{f}=$ false $($ dostęp: 25.01 .2021$)$. 
dokonać nowego rozdziału własności. Contrat Social sankcjonuje prawo ogółu do przeprowadzenia rewolucji totalnej w każdej dziedzinie życia jednostki, grup lub całego społeczeństwa. Przed wolą ogółu nie chronią jednostki żadne prawa, gdyż wszelkie normy mają jedno uzasadnienie: volonté générale.

\section{Fraternité et la volonté générale}

Ideę braterstwa $\mathrm{w}$ doktrynie genewskiego filozofa interpretować można na wiele sposobów. Z pewnością z realnymi szansami na sukces można bronić tezy idealistycznej, upatrując w poglądach Rousseau na braterstwo (nawet uwzględniając towarzyszącą mu wolę powszechną) wyrazu jego osobistej wrażliwości na krzywdę innych - cierpiących, ubogich, niesprawiedliwie traktowanych, upokarzanych, krzywdzonych przez wieki w realiach społeczno-politycznych dotychczas istniejących państw. „Rousseau, jako uosobienie empatii wieku filozofów” to figura, która z pewnością z uznaniem zostałaby przyjęta przez zwolenników jego przekonań, których nie brak w dziejach filozofii politycznej. Do ich grona zaliczyłbym na przykład A. Perietiatkowicza, który co prawda zarzeka się, że absolutnie nie głosi apologii Rousseau ${ }^{48}$, by za chwilę stwierdzić, że „niewielu znamy myślicieli, którzy by wycisnęli tak silne piętno osobiste, uczuciowe na głoszonych przez siebie poglądach. Niewielu wkładało tyle duszy w swoje teorie przeżywało je tak intensywnie, głęboko" 49 .

W tym kontekście idea braterstwa byłaby bliską pojęciu solidarności społecznej. Uznanie, że w miłości oraz w trosce o siebie upatruje on naturalnego źródła ludzkiej odrazy do cierpienia innych ma swoje uzasadnienie. Genewski filozof uznaje współczucie (pitié) jako integralny składnik ludzkiej osobowości. Była to wedle niego jedyna strona kondycji jednostki równoważąca naturalny egoizm. Dzięki niej wspólnota mogła powstać, opierając się na przesłankach pozytywnych („dążenie do dobra”), a nie tylko negatywnych („,ucieczka przez złem”) ${ }^{50}$. Jedyną siłą zdolną zjednoczyć odrębne klasy społeczeństwa w jeden naród, jest współodczuwanie tych, którzy nie cierpią, z cierpiącymi, klas wyższych wobec plebsu. Ten punkt widzenia na pojmowanie, rolę i znaczenie współczucia i współodczuwania w doktrynie Rousseau podsumować można twierdzeniem uznającym autora Contrat Social za myśliciela, który wprowadził współczucie do teorii polityki ${ }^{51}$.

Wizerunek Rousseau, jako szlachetnego idealisty bywa jednak w tym kontekście kwestionowany. Przykładowo C. Pateman twierdzi, że jaskrawą cechę różnych ujęć historii o umowie stanowi brak namysłu nad braterstwem, podczas gdy wolność i równość są bezustannie dyskutowane. Istotę braterstwa w koncepcji

48 A. Peretiatkowicz, Filozofia społeczna J.J. Rousseaus'a, Poznań 1921, s. 2.

49 Ibidem, s. 7.

50 J. Derek, op. cit., s. 34.

51 H. Arendt, O rewolucji, Kraków 1991, s. 80-81. 
woli powszechnej autorstwa Rousseau przedstawia ona z pozycji wojującego feminizmu, jako maskulinistyczny pakt braci ${ }^{52}$.

Pojęcie braterstwa nie jest dla wspomnianej australijskiej badaczki cokolwiek niefortunnym określeniem na międzyludzką solidarność, w rzeczywistości jest to bowiem więź przynależności do egalitarnej męskiej wspólnoty. Kobiety nie mają do niej dostępu, co oznacza, że wyłaniana z takiej umowy społecznej wola powszechna nie jest ich wolą. W braterskiej umowie społecznej chodzi, zdaniem Pateman, właśnie o podporządkowanie kobiet. Umowa społeczna nie jest uniwersalnym demokratycznym zrzeszeniem, jest „braterskim paktem, ustanawiającym społeczeństwo obywatelskie jako porządek patriarchalny" ${ }^{53}$. Umowa społeczna zatem wyłania wspólnotę, w której wszyscy są wolni i równi, o ile są mężczyznami ${ }^{54}$.

\section{Uwagi końcowe}

Delektowanie się smakiem lektury Rousseau dla jednych jest podróżą do intelektualnego Gan Eden, dla innych — doświadczeniem męki Tantala lub w najlepszym razie wyrazem niezaprzeczalnego umiłowania perwersji. Nic jednak nie stoi również na przeszkodzie, by z pozycji bliskich konwencji Foucaulta podejść do problematyki źródeł pochodzenia porządku społecznego uznając, że epistemologiczne ograniczenia związane z poznaniem usytuowanym stanowią ontologiczną szansę na uchwycenie złożoności społecznej bez redukowania jej do przedmiotu jako efektu syntetycznych zdolności oświeconego rozumu ${ }^{55}$. Być może każdy wybór byłby tu jedynie kwestią estetyki, pozbawionej znaczenia z punktu widzenia prowadzonych rozważań.

Sądzę, że warto skonfrontować na przykład opinie Walsha o Umowie społecznej Rousseau ${ }^{56}$ ze zdaniem Szackiego, że Contrat Social, uwzględniając jedynie

52 K. Szumlewicz, Braterska umowa społeczna, czyli filozofia Jana Jakuba Rousseau w ujęciu Carole Pateman, „Przegląd Filozoficzny - Nowa Seria” 21, 2012, nr 4, s. 367.

53 C. Pateman, Braterska umowa społeczna (r. 2 książki The Disorder of Women. Democracy, Feminism and Political Theory, Cambridge 1989), przeł. K. Szumlewicz, http://www.ekologiasztuka.pl/pdf/pateman.pdf, s. 1 (dostęp: 25.01.2021)..

54 K. Szumlewicz, op. cit., s. 371.

55 Por. P. Urbański, op. cit., s. 169. Zob. też M. Foucault, Soba pisanie, przeł. P. Markowski, [w:] idem, Szaleństwo i literatura, Warszawa 1999.

56 Walsh konstatował, że niezależnie od akceptacji tezy, w myśl której konkretne utopie są wyrazem charakterystycznych dla poszczególnych epok zagrożeń, wszystkie one akceptują explicite następujące założenia: człowiek jest zasadniczo dobry, to jest jego zaobserwowane wady są następstwem nie tyle wiecznej natury ludzkiej, ile niesprzyjających warunków życia; człowiek jest istotą plastyczną i łatwo ulega zmianie; nie istnieje żadna nieusuwalna sprzeczność między pomyślnością jednostki a pomyślnością społeczeństwa; człowiek jest istotą rozumną i zdolną do stawania się coraz rozumniejszą, co umożliwia likwidację absurdów życia społecznego i ustanowienie w końcu pełni racjonalnego ładu; przyszłość obejmuje ograniczoną liczbę możliwości i są one całkowicie przewidywalne; należy dążyć do szczęścia na ziemi; ludzie nie mogą odczuwać znużenia szczęściem; możli- 
formę wypowiedzi, można przedstawić jako relację z dobrze rządzonego kraju, analogicznie jak Utopię More'a dałoby się „przełożyć” na projekt konstytucji ${ }^{57}$. Warto je porównać z egzotyką punktu widzenia Poteman czy wnikliwymi interpretacjami Peretiatkowicza oraz stanowiskami wielu innych badaczy, przedstawiających swój sposób myślenia o idei woli powszechnej autora Contrat Social w kontekście sztandarowych haseł Wielkiej Rewolucji Francuskiej.

Jeśli sprowadzimy istotę utopii do uznania, że jej rację bytu stanowi jakaś alternatywa, to Umowa społeczna Rousseau ,jakąś” alternatywą niewątpliwie jest. Tyle tylko, że ubóstwo podobnego uzasadnienia dla „co bardziej wrażliwych” mogłoby okazać się koszmarem nie do zniesienia. Zaliczmy się w ich poczet, wbrew pozorom wcale nie aż tak elitarny. Tym samym jednak nieuchronnie skieruje nas to w stronę wnioskowania przeciwnego, skłaniającego do przychylności wobec uznania antyutopijnego charakteru poglądów obywatela Genewy.

I ten punkt widzenia ostatecznie byłbym skłonny przyjąć, z całym bogactwem inwentarza, czyli pełną świadomością relatywizmu pojęć oraz wątpliwej wartości prostego zakwestionowania antyutopii, jako tylko opozycji wobec utopii pozytywnej. Umacnia mnie w tym przekonaniu nieodparcie towarzyszące mi wrażenie, że uwagi Rousseau na temat woli powszechnej w odniesieniu do idei wolności, równości i braterstwa (tu: solidarności społecznej), niejednokrotnie więcej mają w sobie z sofistyki i makiawelizmu niż wyrafinowanej głębi empatycznego intelektualisty. Oczywiście przy zachowaniu pełnego uznania i szacunku słusznie należnych potencjałowi i efektom badawczym adwersarzy; nawet wówczas, jeśli ich bezkrytycyzm wobec poglądów osiemnastowiecznego uczonego wyda mi się przesadny lub zwyczajnie niezrozumiały. Mogę nie zgadzać się z niemal wszystkimi tezami autora Śmiertelnego boga Demosa ${ }^{58}$, ale zakwestionuję bez chwili refleksji jego opinię, że jakobini byli roussoistami w najgorszej z możliwych projekcji idei obywatela Genewy, a jego poglądy stanowiły fundament rządów jakobińskich i Komitetu Ocalenia Publicznego. Nie będąc zwolennikiem skrajnych opinii, nie odrzuciłbym jednak bez wahania i takiej, która w poglądach Rousseau (na czele z kluczowym dla jego doktryny pojęciem volonté générale) upatruje korzeni totalitaryzmu, narodowego socjalizmu i komunizmu radzieckiego. Jeśli jednak łączenie poglądów filozofa z totalizmem uznać za przesadne, to uznanie w nich kwintesencji komunitaryzmu, z pewnością już przesadą nie będzie. W moim przekonaniu wątpliwy to powód do chwały.

we jest znalezienie sprawiedliwych władców lub nauczenie sprawiedliwości wybranych do rządzenia ludzi; utopia nie zagraża ludzkiej wolności, ponieważ prawdziwa wolność realizuje się właśnie w jej ramach; Ch. Walsh, From Utopia to Nightmare, London 1962, s. 71 n.

57 J. Szacki, op. cit., s. 13.

58 J. Bartyzel, Śmiertelny bóg Demos. Pięć wykładów o demokracji i jej krytykach, Warszawa 2020. 


\section{Bibliografia}

Arendt H., O rewolucji, Kraków 1991.

Bacławski J., Wola powszechna i jej stabilność wedtug koncepcji J.J. Rousseau, „Przegląd Filozoficzny - Nowa Seria” 21, 2012, nr 4.

Baczko M., Rousseau. Samotność i wspólnota, Warszawa 1964.

Baranowska M., Marzenie o szczęściu, czyli idea prawa natury w filozofii Jana Jakuba Rousseau, „Czasopismo Prawno-Historyczne” 65, 2013, z. 2.

Baszkiewicz J., Meller S., Rewolucja Francuska 1789-1794. Społeczeństwo obywatelskie, Warszawa 1983.

Berlin I., Dwie koncepcje wolności i inne eseje, Warszawa 1991.

Blaszke M., Umowa społeczna J.J. Rousseau - polityka i racjonalność, „Archiwum Historii Filozofii i Myśli Społecznej” 32, 1987.

Brandwajn R., Utopia walczaca, Warszawa 1962.

Czerepaniak-Walczak M., Pedagogika emancypacyjna. Rozwój świadomości krytycznej człowieka, Gdańsk 2006.

Derek J., Ideat nowego państwa Jana Jakuba Rousseau i Rewolucja Francuska, „Studia Politicae Universitatis Silesiensis" 2009, nr 4-5.

Foucault M., Soba pisanie, przeł. P. Markowski, [w:] idem, Szaleństwo i literatura, Warszawa 1999.

Graus F., Social Utopias in the Middle Ages, „Past and Present” 1967, nr 38.

Kunicka K., Władza, przymus $i$ wolność w edukacji, „Opuscula Socjologica” 2012, nr 1.

Lévi-Strauss C., Jan Jakub Rousseau, Twórca nauk humanistycznych, przeł. L. Kolankiewicz, „Twórczość" 1984, nr 6.

Ludwisiak M., Postać Jana Jakuba Rousseau i jego wpływ na wspótczesnych, „Acta Universitatis Lodziensis. Folia Historica" 2007, nr 81.

Mead M., Towards More Vivit Utopias, [w:] Utopia, red. G. Kateb, New York 2017.

Melzer A., The Natural Goodness of Man: On the System of Rousseau's Thought, Chicago 1990.

More T., Libellus vere aureus nec minus salutaris quam festivus de optimo reipublicae statu, deque nova insula Utopia, Louvain 1516 [Reprint of the Original from 1516 (Latin Edition), EOD Network 2013].

The Oxford companion to English literature, red. M. Drabble, Oxford 1994.

Peretiatkowicz A., Filozofia społeczna J.J. Rousseaus'a, Poznań 1921.

Peretiatkowicz A., Państwo faszystowskie (Bilans rządów pięcioletnich), „Ruch Prawniczy, Ekonomiczny i Socjologiczny" 1927, nr 4.

Proudhon P.-J., Qu'est-ce que la Propriété?, ou, recherches sur le principe du droit et du gouvernement. Premier mémoire, Paris 1840.

Rawls J., Wyktady z historii filozofii polityki, Warszawa 2010.

Rousseau J.J., Umowa społeczna, przeł. A. Peretiatkowicz, Kęty 2007.

Rutkowski P., Polityczne korzenie „Utopii” Tomasza Morusa, „Odrodzenie i Reformacja w Polsce” 45, 2001.

de Saint-Just A.L., Wybór pism, przeł. J. Ziemilski, B. Kulikowski, Warszawa 1954.

Szacki J., Spotkania z utopia, Warszawa 2000.

Szumlewicz K., Braterska umowa społeczna, czyli filozofia Jana Jakuba Rousseau w ujęciu Carole Pateman, „Przegląd Filozoficzny — Nowa Seria” 21, 2012, nr 4.

Świętochowski A., Utopie w rozwoju historycznym, Warszawa 1910.

Urbański P., Jean Jacques Rousseau: oświecenie a soba-pisanie, „Filozofia i Nauka. Studia filozoficzne i interdyscyplinarne" 5, 2017.

Weber M., Gospodarka i społeczeństwo. Zarys socjologii rozumiejącej, Warszawa 2002.

Studia nad Autorytaryzmem i Totalitaryzmem 43, nr 2, 2021

(C) for this edition by CNS 


\section{Witryny internetowe}

1758-août 1761, Bibliothéque publique et universitaire de Geneve (première version); "Le manuscrit contenant la version définitive du Contrat social qui a été imprimée a disparu." le Pléiade édition t. III, p.1866. Publication, Amsterdam, février-mars 1762, Marc Michel Rey, etc.; le Pléiade édition t. III, pp. 347-470, 1866-1874. Du Peyrou/Moultou 1780-1789 quarto édition; t. I, pp. 187-360 (1782), https://www.rousseauonline.ch/Text/du-contrat-social-ouprincipes-du-droit-politique.php.

Bartyzel J., Jakobini byli roussoistami, https://teologiapolityczna.pl/prof-jacek-bartyzel-jakobini-byli-roussoistami.

Bertram Ch., Jean Jacques Rousseau, [hasło w:] The Stanford Encyclopedia of Philosophy (wydanie zimowe 2020), red. Edward N. Zalta, https://plato.stanford.edu/archives/win2020/entries/rousseau.

Duignan B., Jean-Jacques Rousseau, [hasło w:] Britannica, https://www.britannica.com/biography/ Jean-Jacques-Rousseau.

Głażewski M., Terra Utopia. Glosy i konteksty pedagogiczne utopii, http://www.repozytorium.uni. wroc.pl/Content/89288/PDF/3_Glazewski_Michal_Terra_utopia.pdf.

Pateman C., The Disorder of Women. Democracy, Feminism and Political Theory, przeł. K. Szumilewicz, http://www.ekologiasztuka.pl/pdf/pateman.pdf.

Porada A., Jan Jakub Rousseau - filozof w stanie natury, https://www.polityka.pl/tygodnikpolityka/historia/1528293,1,jan-jakub-rousseau---filozof-w-stanie-natury.read.

Vanderstappen T., Thomas More and his Utopia: The Leuven Connection, „The Brussels Times”, 7.11.2016, https://www.brusselstimes.com/opinion/39946/thomas-more-and-his-utopia-the-leuven-connection/. 